\title{
Hőátadási tényező meghatározása köpenytéri hőátadás esetén
}

\author{
Szőr István \\ BSc hallgató, Miskolci Egyetem \\ Energetikai és Vegyipari Gépészeti Intézet, Vegyipari Gépészeti Intézeti Tanszék \\ 3515 Miskolc, Miskolc-Egyetemváros, email: szor.steven@gmail.com \\ Szepesi L. Gábor \\ egyetemi docens, Miskolci Egyetem \\ Energetikai és Vegyipari Gépészeti Intézet, Vegyipari Gépészeti Intézeti Tanszék \\ 3515 Miskolc, Miskolc-Egyetemváros, email: szepesi@uni-miskolc.hu
}

\begin{abstract}
Absztrakt
Ezen cikk témája az iparban használatos csőköteges höcserélők köpenytéri höátadási tényezőjének meghatározási módszereinek áttekintése. Bár néhány irodalom megtalálható a témával kapcsolatban, viszont magyar forditásban meglehetösen kisszámú forrás érhetö el.

A köpenytéri höátadási tényezőt számos, a höcserélö geometriájától függő módositó tényezö befolyásolja. Ezen tényezök: a terelölemez vágási korrekciós tényezö, a terelölemez hézag korrekciós tényezö, a csőköteg bypass korrekciós tényezö, az egyenlötlen áramlási zóna korrekciós tényezö, a falviszkozitási korrekciós tényezö valamint az ideális csőköteg höátadási tényezö. Jelen publikációban ezen módositó tényezők számitási módszerei és jellemzö értékei kerülnek bemutatásra.
\end{abstract}

Kulcsszavak: höcserélö, köpenytéri höátadás, konvekció

\begin{abstract}
In this paper methods of determining heat transfer coefficient in shell side of shell-and-tube heat exchangers were reviewed. Although some literature can be found in the topic, there are few sources available in Hungarian translation.

Heat transfer coefficients of shell side are influenced by a number of modifying factors depending on the geometry of the heat exchanger. These factors include the baffle cut correction factor, the baffle leakage correction factor, the bundle bypass correction factor, the unequal baffle spacing correction factor, the wall viscosity correction factor, laminar flow correction factor, and the ideal tube bank heat transfer coefficient. Methods and characteristic values of these modifying factors had been demonstrated in this publication.
\end{abstract}

Keywords: shell-and-tube heat exchanger, shell-side heat transfer, convection

\section{Bevezetés}

$\mathrm{Az}$ ipari készülékekben végbemenő hőcserélődési folyamatokat összefoglaló néven hőátszármaztatásnak, illetve hőátvitelnek nevezzük. A hőátvitel különböző hőmérsékletű testek közötti energiaátvitelt jelent, hőenergia formájában. A hő áramlása, a hőközlés mindig hőmérséklet-különbség hatására jön létre, és a termodinamika második főtétele alapján mindig a magasabb hőmérsékletủ helyről áramlik az alacsonyabb hőmérsékletủ hely felé [1]. A hőátvitelnek három alapvető formája van: a hővezetés, a hőáramlás (konvekció, hőszállítás) és a hősugárzás.

A hőszállítás, más néven konvekció csak folyékony és gáznemü közegeknél jelentkezhet, ugyanis az anyag makroszkopikus részecskéinek elmozdulásával, helyváltoztatásával jön létre. A közeg rend- 
szerint a szilárd testnek - általában falnak- adja át-, esetleg veszi fel arról a hőt. Ez a folyamat a hőátadás. Figyelembe szokás venni, hogy az áramlást mi okozza. Különbséget teszünk szabad-, illetve kényszeráramlásos konvekció között. Az előbbinél a folyadékban vagy gázban helyi hőmérsékletkülönbségek vannak, amiknek megfelelöen sürüségkülönbség keletkezik, így kialakul az áramlás. Az utóbbinál valamilyen külső kényszer hatására jön létre az áramlás, pl. keverés hatására [2].

A konvekciós hőátvitel annál intenzívebb, minél nagyobb a turbulencia az áramlásban és minél intenzívebb a részecskék keveredése [3]. Az is ismeretes, hogy a fázisváltozással járó hőcsere hatásosabb, mint a fázisváltozás nélküli eset. Egy faltól távozó vagy egy ahhoz áramló közeg hőátadásánál a hőáramot az ún. Newton-féle lehülési törvénnyel tudjuk kifejezni:

$$
\dot{Q}=\alpha A\left(t_{f}-t_{m}\right)
$$

ahol : $\quad \dot{Q}$ - hőáram, az időegység alatt átadott hőmennyiség, $[W]$

$A$ - a höátadó felület, $\left[\mathrm{m}^{2}\right]$

$t_{f}$ - a közeggel érintkező fal felületének hőmérséklete, $\left[K,{ }^{\circ} \mathrm{C}\right]$

$t_{m}$ - a közeg mértékadó hőmérséklete, $\left[K,{ }^{\circ} \mathrm{C}\right]$

$\alpha$ - a höátadási tényező, $\left[W / m^{2} K\right]$

Ez az egyenlet az $\alpha$ hőátadási tényezőt definiálja. Az $\alpha$ hőátadási tényező azt a hőmennyiséget jelenti, amely $1 \mathrm{~m}^{2}$ hőátadó felületen, egységnyi idő alatt, $1 \mathrm{~K}$ hőmérséklet-különbség esetén az áramló fluidum és a felület között átmegy. Tapasztalat szerint a forrásban lévő folyadékok és kondenzálódó gőzök esetében az $\alpha$ értéke kiemelkedően nagy, nagyságrendje akár 10000-es is lehet.

Külön kell vizsgálni az olyan eseteket, amikor a hőátadás természetes áramlásból ered, és külön, amikor kényszerkonvekció eredménye. Szintén külön kell figyelembe venni a fázisváltozással járó eseteket.

\section{Köpenytéri hőátadási tényező meghatározása}

A köpenytéri hőátadási tényezőt számos paraméter befolyásolja, melyet a számítások alkalmával figyelembe kell venni. Továbbá ezen tényezők segítségével határozható meg a köpenytéri hőátvitel sebessége is. Összességében az alábbi megfontolások érvényesek a csőköteges hőcserélők hőátadására vonatkozóan:

1. Ha a höcserélö terelölemezekkel ellátott, akkor a rendszerben irányított köpenyoldali folyadékmozgás alakul ki, amely az axiális áramlástól eltérve, felülről lefelé áramló vagy az oldalak közti áramlást eredményez, így nagyobb hőátadási tényezőt eredményezve, mint a csövek tengelye mentén zajló zavartalan áramlás esetén [4].

2. A cső elrendezésének mintázata befolyásolja a turbulenciát és így a hőátadási tényezőt is, például a háromszög alakú elrendezés nagyobb turbulenciát eredményez, mint a négyszög. Közel azonos áramlási feltételek és csőméretek mellett összehasonlítva a két különböző típusú csőosztást, a hőátviteli együttható körülbelül 25\%-kal nagyobb háromszög elosztás esetén, mint a négyszögnél [5].

3. Minél szorosabb a terelölemezek elhelyezése, annál gyakrabban változik a köpenytéri folyadék áramlásának iránya, ami szintén nagyobb turbulenciát eredményez [6].

4. A köpenytéri hőátadási tényezőt a cső mérete, az azok közötti távolságok és a folyadékáramlás jellemzői is befolyásolják [7]. 
5. A csőköteg átmérője mentén haladva, a hosszirányban vett csősorok számának változásával módosul a köpenytéri áramlási terület. Ebből kifolyólag nem lehet pontosan meghatározni az áramlási területet, így a köpenytéri folyadék sebessége sem határozható meg teljes pontossággal.

6. A csövekben áramló folyadékoknál kapott korreláció nyilvánvalóan nem alkalmazható a csőkötegeken átáramló folyadékokra, amelyek a terelőlemezekkel szegmensekre vannak osztva [5].

7. A hőcserélők tervezése, illetve ellenőrzésekor előfordulnak olyan kifejezések, amelyek gyakran zavarosak. Ezek a „méretezés”, a „tervezés” és a „kiválasztás”.

A „méretezés” az a számítási folyamat, amelyben meghatározzuk a hőcserélő kimeneti paramétereit, úgymint a kimenő hőmérsékleteket és a készülék hőteljesítményét (ha a hőcserélő hossza adott) vagy a hőcserélö szükséges hosszát a bemeneti paramétereket felhasználva. Bemeneti paraméterek lehetnek például az áramlási sebesség, a hőmérséklet és a folyadék tulajdonságai [4].

A „tervezés” azt a folyamatot takarja, melynek során egy olyan hőcserélő összes lényeges konstrukciós méretét meghatározzuk, mely egy adott hőteljesítmény leadására vagy felvételére képes, és megfelel a köpenyoldali és a csőoldali nyomásesés korlátozásainak. A „Kiválasztás” a már meglévő készülékek közül választja ki a szükséges hőcserélőt [4].

A legtöbb tervezö olyan, a mérnöki gyakorlaton alapuló empirikus összefüggéseket alkalmaz, melyek az ő ítélóképességüktől és tapasztalatuktól függően alkalmazhatók az általuk méretezett készülékekre. Azonban a kevésbé tapasztalt tervezők számára követhetőbb módszer az analitikus megközelítés, mivel az alapvető fizikai összefüggéseken nyugszik. Ebben a tanulmányban elsődlegesen a Wolverine által kifejlesztett analitikai megközelítésen alapuló termikus elemzés került felhasználásra [8]. Ebben a cikkben a szegmensekre bontott terelőlemezes hőcserélőben történő hőátadás vizsgálatakor alkalmazott számítási módszert ismertetjük, összefoglalva az elérhető szakirodalmakban leírt ismereteket.

\subsection{Köpenytéri hőátadási tényező}

A köpenytéri hőátadáskor számítandó $\alpha_{k}$ hőátadási tényező a következőképp írható fel:

$$
\alpha_{k}=\alpha_{I}\left(J_{C} \cdot J_{L} \cdot J_{B} \cdot J_{R} \cdot J_{S} \cdot J_{\eta}\right)
$$

ahol: $\quad \alpha_{I}-$ höátadási tényező terelőlemez nélküli csőkötegre számítva

$J_{C}$ - (cut) terelőlemez vágási korrekciós tényező

$J_{L}$ - (leakage) terelőlemez hézag korrekciós tényező

$J_{B}$ - bypass korrekciós tényezö

$J_{R}$ - lamináris áramlási korrekciós tényező

$J_{S}$ - (space) egyenlőtlen áramlási zóna korrekciós tényező

$J_{\eta}$ - fal viszkozitási korrekciós tényező

Az egyenletben szereplő tényezők a következőkben vannak részletesebben feltüntetve. A leírásokban szereplő geometriai méretek értelmezéseit szemléltetik az 1-4. ábrák.

A 3. ábra Terelőlemez és csőköteg geometria [8] látható $D_{S}, D_{o t l}$, terelőlemez vágás $\left(B_{c}\right.$ ami a $D_{S}$ \%-os aránya), $L_{b b}, L_{s b}$ a hőcserélőben lévő csövek elosztásából meghatározható. Abban az esetben, ha a $D_{\text {otl }}$ nem ismert, az $L_{b b}$ az alábbi értékre becsült:

- $D_{S}<300 \mathrm{~mm} \rightarrow L_{b b}=9,525 \mathrm{~mm}$

- $300 \mathrm{~mm}<D_{S}<1000 \mathrm{~mm} \rightarrow L_{b b}=12,7 \mathrm{~mm}$

- $1000 \mathrm{~mm}<D_{S} \rightarrow L_{b b}=15,875 \mathrm{~mm}$ 


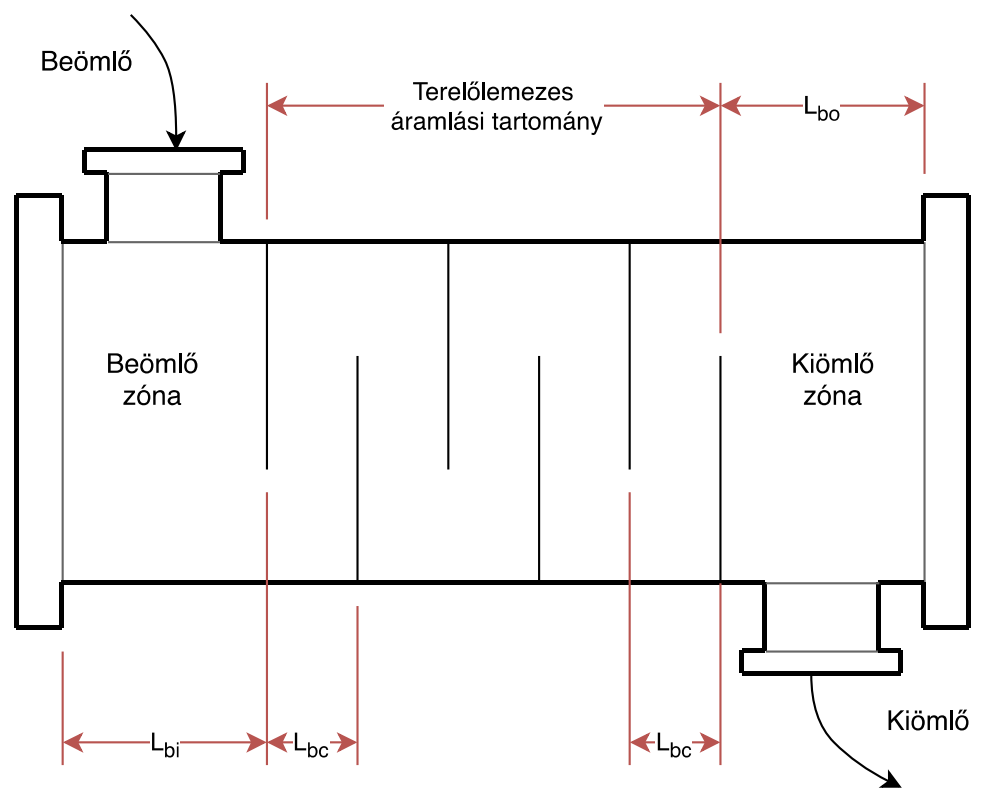

2. ábra Terelölemezes höcserélő szakaszai [9]

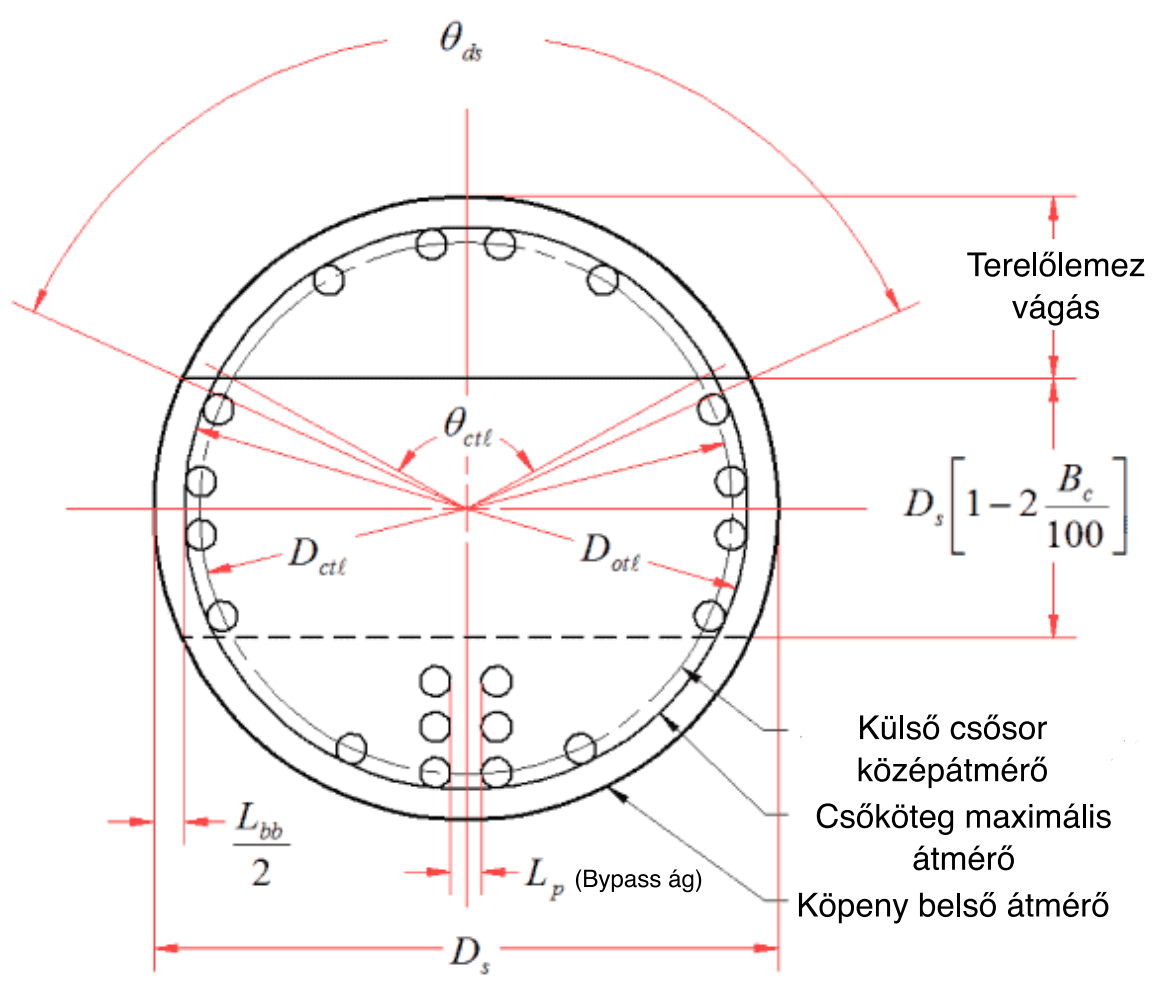

3. ábra Terelölemez és csököteg geometria [8] 


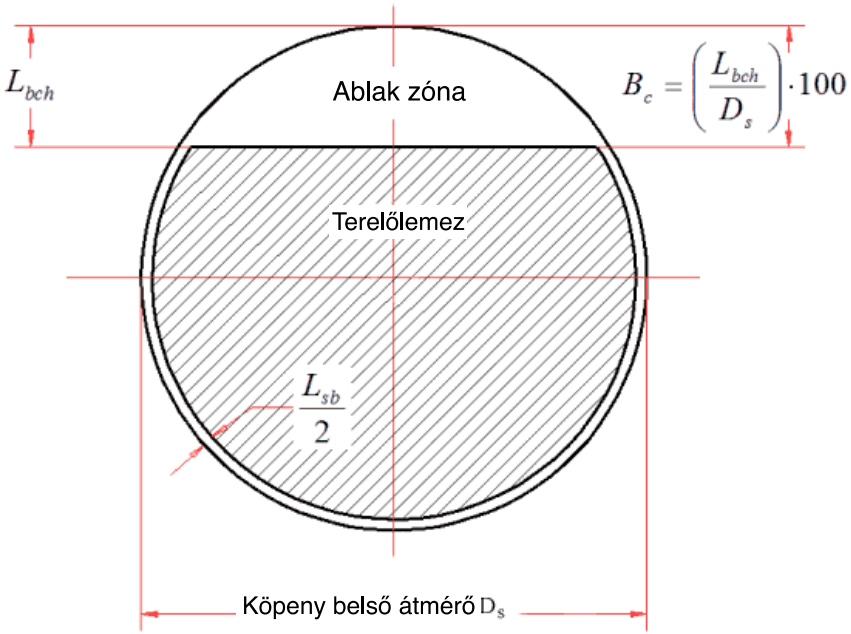

4. ábra Terelölemez vágás és hézag [8]

Hasonlóan az előzőhöz, ha nem ismert az $L_{s b}$, az értékei az alábbiak lehetnek:

- $D_{S}<400 \mathrm{~mm} \rightarrow L_{s b}=2 \mathrm{~mm}$

- $400 \mathrm{~mm}<D_{S} \rightarrow L_{s b}=1,6+0,004 \cdot D_{S}[\mathrm{~mm}]$
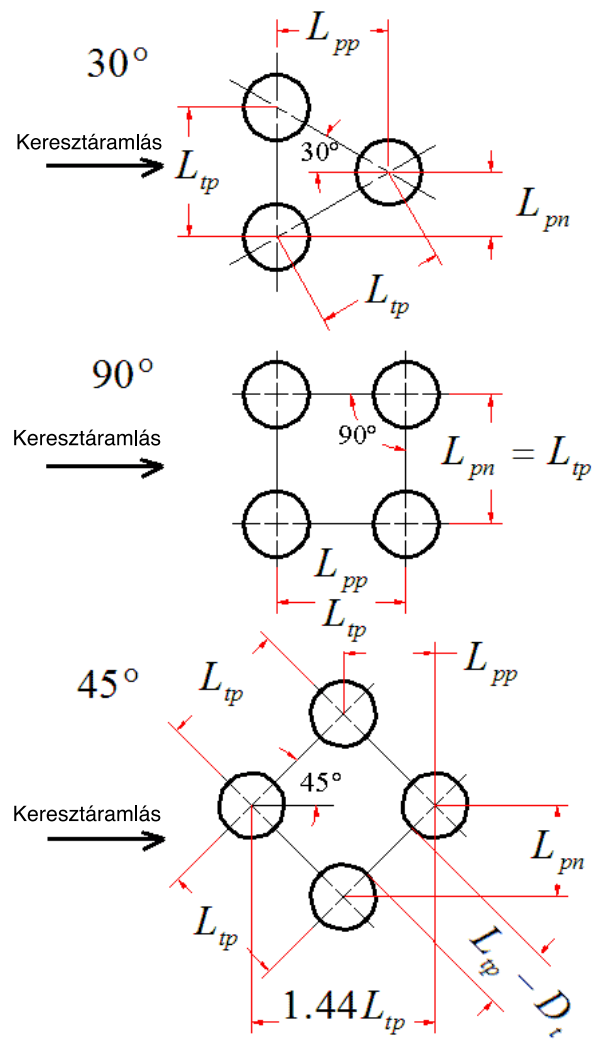

4. ábra Csóelosztások [8]

120 


\subsection{Terelőlemez vágási korrekciós tényező}

A terelőlemez vágási korrekciós tényezőjét akkor szükséges meghatározni, amikor az ablakban történő áramlás sebessége nem egyenlő a csőköteg közötti áramlás sebességével, így az áramlás eltér az ideálistól. A sebességkülönbség nagysága az ablak méretével áll egyenes arányban. Az ablakban való áramlás a csövekre való tekintettel fóként hosszirányú, ami kevésbé hat ki a hőátadás mértékére, mint a csövekre merőleges áramlás. A $J_{c}$ a következőképp számítható:

ahol:

$$
J_{C}=0,55+0,72 F_{C}
$$

$$
F_{C}=1-2 F_{W}
$$

A kifejezésben szereplő $F_{W}$ (window) az ablak áramlás szempontjából elfoglalt része.

$$
F_{W}=\frac{\theta_{c t l}}{360}-\frac{\sin \theta_{c t l}}{2 \pi}
$$

A $\theta_{c t l}$ terelőlemez vágási szöge a hőcserélő középvonalán számítva:

$$
\theta_{c t l}=2 \cdot \cos ^{-1}\left\{\frac{D_{s}}{D_{c t l}}\left[1-2\left(\frac{B_{c}}{100}\right)\right]\right\}
$$

A $J_{c}$ értéke általában 0,65 és 1,175 közé tehető.

\subsection{Terelőlemez hézag korrekciós tényező}

A szomszédos terelölemezek közötti nyomáskülönbség hatására a közeg a terelölemez és a benne található csövek közötti réseken áramlik át, ami kismértékben csökkenti a hőátadási tényező értékét. A maximális $J_{L}$ érték 1. Vízhütéses kondenzátoroknál általában 0,85 és 0,9 közötti értéket vesz fel, konstrukciótól függően. Mivel ez a hatás viszonylag kismértékủ, így elhanyagolható.

\subsection{Csőköteg bypass korrekciós tényező}

A $J_{B}$ csőköteg korrekciós tényező annak a visszaáramlásnak a figyelembe vételére számolandó, ami a köpeny fala és a csőköteg között jön létre. Ez a hatás nem mindig következik be, valamint kiküszöbölhető áramlásterelő behelyezésével a köpenyfal és a csőköteg közé. A vezetőket párban szokás elhelyezni, és maximum egy pár behelyezése ajánlott minden második csősor közé, ahol két terelölemez között az áramlás történik. $\mathrm{A} J_{B}$ értéke az alábbi módon számolható:

$$
J_{B}=e^{-C_{b h} \cdot F s b p\left(1-\sqrt{2 r_{s S}}\right)}
$$

ahol: $\quad C_{b h}$ - tapasztalati faktor, ami lamináris esetben $(R e \leq 100) 1,35$, egyéb esetben 1,25

$F_{s b p}$ - a bypass (kerülés)-ra vonatkozó viszonyszám

$r_{s S}$ - az áramlás terelőkre vonatkozó viszonyszám 


\subsection{1. $F_{\text {sbp }}$ meghatározása}

ahol:

$$
F_{s b p}=\frac{S_{b}}{S_{m}}
$$

$$
S_{b}=L_{b c}\left[\left(D_{s}-D_{o t l}\right)+L_{p l}\right]
$$

$L_{p l}$ a bypass áramlás szélessége a csövek között. Normál áramlás esetén $L_{p l}=0$, bypass áramlás esetén $L_{p l}=1 / 2$.

$$
S_{m}=L_{b c}\left[L_{b b}+\frac{D_{c t l}}{L_{t p, e f f}}\left(L_{t p}-D_{t}\right)\right]
$$

$L_{t p, e f f}: \quad 30^{\circ}$ és $90^{\circ}$-os csőelrendezésnél $L_{t p, e f f}=L_{t p}, 45^{\circ}$-os elrendezésnél:

$$
L_{t p, e f f}=0,707 L_{t p}
$$

\subsection{2. $r_{s s}$ meghatározása}

$$
r_{S S}=\frac{N_{S S}}{N_{t c}}
$$

ahol:

$$
N_{t c}=\frac{D_{s}}{L_{p p}}\left[1-\left(\frac{B_{c}}{100}\right)\right]
$$

$$
\begin{aligned}
L_{p p}: 30^{\circ} \text {-nál } L_{p p} & =0,866 L_{t p} \\
45^{\circ} \text {-nál } L_{p p} & =0,707 L_{t p} \\
90^{\circ} \text {-nál } L_{p p} & =L_{t p}
\end{aligned}
$$

$N_{s s}$ : párban számolt áramlásterelők száma egy terelőlemez esetén, az áramlás vonalában lévő csősorok esetén.

Ezen összefüggések alapján a $J_{B}$ maximális értéke 1 lehet, $r_{S S} \geq 1 / 2$ esetén.

\subsection{Egyenlőtlen áramlási zóna korrekciós tényező}

Ez a tényező abban az esetben számolandó, ha a be- és kiömlő szakasz nagyobb, mint egy-egy terelölemez közötti kamra. Ez a tényező az áramlási sebességre való hatása miatt jelentős. Abban az esetben, ha a be- illetve kiáramlási szakasz egyenlő a terelőlemezek közötti szakaszokkal, úgy a $J_{S}=1$ értéket vesz fel. Ha az előbbi szakaszok nagyobbak az utóbb említetteknél, úgy a $J_{S}<1$, amit az alábbi egyenlet segítségével határozhatunk meg:

$$
J_{S}=\frac{\left(N_{b}-1\right)+\left(L_{b i} / L_{b c}\right)^{1-n}+\left(L_{b o} / L_{b c}\right)^{1-n}}{\left(N_{b}-1\right)+\left(L_{b i} / L_{b c}\right)+\left(L_{b o} / L_{b c}\right)}
$$

ahol: $\quad N_{b}-$ a terelölemezek közötti kamrák száma $n$ értéke lamináris esetben $1 / 3$, turbulens esetben 0,6 . 


\subsection{Lamináris áramlási korrekciós tényező}

Lamináris áramlás esetén kisebb hőátadási tényező adódik, mint turbulens esetben. $R e>100$ esetén nincs szükség korrekciós tényezőre, ilyenkor $J_{R}=1$. Ha $R e \leq 20$, a korrekció az alábbi összefüggéssel számolható:

$$
J_{R}=\left(J_{R}\right)_{20}=\left(\frac{10}{N_{c}}\right)^{0,18}
$$

ahol: $N_{c}$ - az áramlás által keresztirányban érintett csősorok száma az egész hőcserélőben

$$
N_{c}=\left(N_{t c c}+N_{t e w}\right)\left(N_{b}+1\right)
$$

$N_{t c c}$ - a terelőlemezek közötti területen vett keresztirányú áramlásnak kitett csősorok száma, aminek számolási módja az előzőkben már fel lett tüntetve.

$N_{\text {tew }}$ - az ablakban lévő csősorok száma

$$
N_{\text {tew }}=\frac{0,8}{L_{p p}}\left[D_{S}\left(\frac{B_{c}}{100}\right)-\frac{D_{S}-D_{c t l}}{2}\right] .
$$

Ha $20<R e<100$, akkor

$$
J_{R}=\left(J_{R}\right)_{20}+\left(\frac{20-R e}{80}\right)\left[\left(J_{R}\right)_{20}-1\right]
$$

A $J_{R}$ minimum értéke 0,4 .

\subsection{Fal viszkozitási korrekciós tényező}

Hővezetés korrekciós tényezőit közepes anyagjellemzök alapján szokás meghatározni, amit a be- és kimeneti hőmérséklet átlagán veszünk. Folyadékok fütésekor és hütésekor a közepes fluidum hőmérséklet és a falhőmérséklet között vett eltérö anyagtulajdonságok miatt vesszük figyelembe a korrekciós tényezőt, amit a közeg közepes $\eta$ dinamikai viszkozitása és az $\eta_{f a l}$ falnál mért viszkozitása alapján számolunk.

$$
J_{\eta}=\left(\frac{\eta}{\eta_{f a l}}\right)^{m}
$$

A korrekciós tényező fütés esetén nagyobb, mint 1, hütéskor pedig egynél kevesebb. Folyadékok hütése, illetve fütése esetén az $m=0,14$ értéket vesz fel.

Gázok esetén, hütéskor nem szükséges korrekciós tényezőt alkalmazni. Fütéskor viszont a korrekció alapja a viszkozitás helyett hőmérsékletet veszünk, így az összefüggés:

$$
J_{\eta, g a ́ z}=\left(\frac{T+273}{T_{f a l}+273}\right)^{0,25}
$$


ahol: $\quad T$ - a közepes hőmérséklet

$T_{\text {fal }}$ - a fal hőmérséklete

Ahhoz, hogy meg lehessen határozni a falhőmérsékleten vett viszkozitást, a hőátadáskor kialakult fal hömérséklete szükséges.

\subsection{Terelőlemez nélküli csőköteg hőátadási tényező}

A terelölemez nélküli csőköteg hőátadási tényezőjét a teljes csőköteg csövei közötti áramlásból számoljuk:

$$
\alpha_{I}=j_{I} \cdot c_{p} \cdot \dot{m} \cdot \operatorname{Pr}^{-2 / 3}
$$

A fluidum tömeg sebessége $\dot{m}$, mértékegysége $\mathrm{kg} / \mathrm{m}^{2} s . \operatorname{Pr}$ a Prandtl-szám. A $j_{I}$ a hőátadási faktor, amit az alábbi módon számolunk:

$$
j_{I}=a_{1}\left(\frac{1,33}{L_{t p} / D_{t}}\right)^{a} \cdot R e^{a_{2}}
$$

ahol:

$$
a=\frac{a_{3}}{1+0,14 R e^{a_{4}}} .
$$

Az $a_{1}, a_{2}, a_{3}, a_{4}$ értékei az alábbi Taborek (1983) [8] által megadott 1. táblázatban találhatók. A köpenytéri keresztirányú áramláskor, a csőköteg maximális áramlási keresztmetszetén vett tömegsebesség egyenlete:

$$
\dot{m}=\frac{M}{S_{m}}
$$

$S_{m}$-et előzőkben meghatároztuk, $M$ pedig a köpenytéri áramlás tömegárama, aminek mértékegysége $\mathrm{kg} / \mathrm{s}$.

A köpenytéri Reynolds-szám:

$$
R e=\frac{D_{t} \cdot \dot{m}}{\eta_{h v}}
$$

ahol: $\quad D_{t}-$ a csövek külső átmérője

A Prandtl-szám pedig az alábbi módon számolható:

$$
\operatorname{Pr}=\frac{c_{p} \cdot \eta}{\lambda}
$$

ahol: $\quad c_{p}$ - fajhő

$\eta$ - dinamikai viszkozitás

$\lambda$ - hővezetési tényező

Az anyagjellemzőket a fluidum közepes hőmérsékleten vesszük figyelembe.

A hőátadó felület $A_{o}$ meghatározásához a csövek effektív csőhosszúságát $L_{t a}$-t használjuk fel:

ahol: $\quad N_{t t}-$ a csőkötegben található csövek száma.

$$
A_{o}=\pi \cdot \mathrm{D}_{\mathrm{t}} \cdot \mathrm{L}_{\mathrm{ta}} \cdot \mathrm{N}_{\mathrm{tt}}
$$


Az 1. táblázat a már említett $a$ értékek mutatja.

1. táblázat Empirikus együtthatók a j j meghatározásához.[8]

\begin{tabular}{|c|c|c|c|c|c|c|c|c|c|}
\hline Elrendezés & $R e$ & $a_{1}$ & $a_{2}$ & $a_{3}$ & $a_{4}$ & $b_{1}$ & $b_{2}$ & $b_{3}$ & $b_{4}$ \\
\hline \multirow{5}{*}{$30^{\circ}$} & $10^{5}-10^{4}$ & $\begin{array}{r}0 . \\
321\end{array}$ & -0.388 & \multirow{5}{*}{1.450} & \multirow{5}{*}{0.519} & 0.372 & -0.123 & \multirow{5}{*}{7.00} & \multirow{5}{*}{0.500} \\
\hline & $10^{4}-10^{3}$ & 0.321 & -0.388 & & & 0.486 & -0.152 & & \\
\hline & $10^{3}-10^{2}$ & 0.593 & -0.477 & & & 4.570 & -0.476 & & \\
\hline & $10^{2}-10$ & 1.360 & -0.657 & & & 45.10 & -0.973 & & \\
\hline & $<10$ & 1.400 & -0.667 & & & 48.00 & -1.000 & & \\
\hline \multirow{5}{*}{$45^{\circ}$} & $10^{5}-10^{4}$ & 0.370 & -0.396 & \multirow{5}{*}{1.930} & \multirow{5}{*}{0.500} & 0.303 & -0.126 & \multirow{5}{*}{6.59} & \multirow{5}{*}{0.520} \\
\hline & $10^{4}-10^{3}$ & 0.370 & -0.396 & & & 0.333 & -0.136 & & \\
\hline & $10^{3}-10^{2}$ & 0.730 & -0.500 & & & 3.500 & -0.476 & & \\
\hline & $10^{2}-10$ & 0.498 & -0.656 & & & 26.20 & -0.913 & & \\
\hline & $<10$ & 1.550 & -0.667 & & & 32.00 & -1.000 & & \\
\hline \multirow{5}{*}{$90^{\circ}$} & $10^{5}-10^{4}$ & 0.370 & -0.395 & \multirow{5}{*}{1.187} & \multirow{5}{*}{0.370} & 0.391 & -0.148 & \multirow{5}{*}{6.30} & \multirow{5}{*}{0.378} \\
\hline & $10^{4}-10^{3}$ & 0.107 & -0.266 & & & 0.0815 & +0.022 & & \\
\hline & $10^{3}-10^{2}$ & 0.408 & -0.460 & & & 6.090 & -0.602 & & \\
\hline & $10^{2}-10$ & 0.900 & -0.631 & & & 32.10 & -0.963 & & \\
\hline & $<10$ & 0.970 & -0.667 & & & 35.000 & -1.000 & & \\
\hline
\end{tabular}

\section{3. Összefoglalás}

Ebben a cikkben sorra lett véve a csőköteges hőcserélők köpenytéri hőátadására vonatkozó szakirodalom. Mivel a köpenytéri hőátadási tényező számos geometriai paramétertől függ, így ezek hatását minden egyes számításnál figyelembe kell venni. Összefoglalást nyertek ezen paraméterek hatásai, számítási módjai valamint ezek jellemző értékei. A vizsgálatok során kiderült, hogy bizonyos tényezők elhanyagolhatók, - mint például a terelőlemez vágási korrekciós tényezö - ám a többség hatása nem mellékes a köpenytéri höátadás szempontjából.

\section{Köszönetnyilvánítás}

A cikkben ismertetett kutató munka az EFOP-3.6.1-16-2016-00011 jelü „Fiatalodó és Megújuló Egyetem - Innovatív Tudásváros - a Miskolci Egyetem intelligens szakosodást szolgáló intézményi fejlesztése" projekt részeként - a Széchenyi 2020 keretében - az Európai Unió támogatásával, az Európai Szociális Alap társfinanszírozásával valósul meg. 


\section{Irodalomjegyzék}

[1] Z. Fonyó and G. Fábry, Vegyipari müvelettani alapismeretek. Budapest: Nemzeti Tankönyvkiadó Rt., 2004.

[2] G. Fejes and G. Fábry, Vegyipari gépek és müveletek II. Budapest: Tankönyvkiadó Vállalat, 1975.

[3] A. G. Kaszatkin, Alapmüveletek, gépek és készülékek a vegyiparban, 3rd ed. Budapest: Müszaki Könyvkiadó, 1976.

[4] M. Peters, K. Timmerhaus, and R. West, Plant Design and Economics for Chemical Engineers, 4th ed. McGraw-Hill Book Company, 1958.

[5] TEMA, "Turbukar Exchanger Manufacturers Association,8th ed," New York, 1999.

[6] W. M. Kays and A. L. London, Compact Heat Exchangers, 3rd ed. Krieger Publishing Malabar, 1998.

[7] A. S. Sukomel and E. A. Krasnoshchekov, Problems in Heat Transfer. Moscow: MIR Publishers, 1977.

[8] J. R. Thome, "Single-Phase Shell-Side Flows and Heat Transfer," in Engineering Data Book III, no. 1983, 2010, pp. 1-20.

[9] K. J. Bell and A. C. Muller, Wolverine Tube Heat Transfer Data Book II. Wolverine Division of UOP Inc, 1984. 